\title{
Pre- and post-mine land-use trends across the New South Wales and Queensland coal industry
}

\author{
K Fogarty The University of Western Australia, Australia \\ ME Kragt The University of Western Australia, Australia \\ B White The University of Western Australia, Australia
}

\begin{abstract}
Mining is a temporary land use and there is a need to transition to an acceptable land use after mining ceases. This typically includes grazing or reinstatement of native ecosystems present prior to disturbance (Doley \& Audet 2013; Lechner et al. 2016; Maczkowiack et al. 2012). However, no published information exists that informs of the collective plans for the coal mining industry's proposed post-mining land uses.

This study uses publicly available information on pre-mine and proposed post-mine land uses for coal mines in Queensland and New South Wales, Australia. We will discuss what pre-mining land uses are typically identified and how this definition changes post-mining. Terminology used by mining companies to describe their pre- and post-mine land use is also presented. This information will be useful to identify future beneficial land uses as well as support decision-making and policymaking at a landscape level.

Results indicate that agriculture and biodiversity are the most commonly proposed post-mine land uses compared to agriculture being the dominant pre-mining land use. Sites also frequently nominated multiple post-mine land uses, with over $85 \%$ of sites nominating between one and three post-mine land uses. Sites tend to increase the number of identified land uses when nominating their post-mine land use compared to the number identified during pre-mining. Results also found limited evidence to suggest that operations are likely to revert to the pre-mining land use, with about half of sites planning to reinstate the pre-mining land use(s), even with additional land uses, after mine closure. Furthermore, it was observed that some mine sites tend not to provide an explicit statement or consider the utility of post-mining land use when detailing the post-mine land use(s).
\end{abstract}

Keywords: land use change, mine rehabilitation, mining land use terminology

\section{Introduction}

Australia's resources and energy export earnings are forecast to reach a record high of AUD 278 billion in 2018-2019 (Department of Industry, Innovation and Science 2019), making mining one of the nation's highest value land use activities (Minerals Council of Australia 2017). Although Australia derives great economic and social benefit from mining, mining also creates environmental impacts, alters landscapes and brings social changes to communities. Mining is a temporary land use, and in the mining context, sustainability and regulatory obligations dictate the need to transition to an acceptable land use after mine closure. This includes a requirement to create stable non-polluting landforms, carry out progressive rehabilitation, and identify post-mining land uses that benefit local and regional communities (Department of Industry 2016). In Australia, this typically includes grazing or reinstatement of the native ecosystems present prior to disturbance (Doley \& Audet 2013; Lechner et al. 2016; Maczkowiack et al. 2012). However, no published information currently exists that informs of the collective plans for proposed post-mining land uses and how they vary across state jurisdictions.

Coal is the most abundant fossil fuel (World Energy Council 2015). Whilst coal deposits exist in every state in Australia (Geoscience Australia 2017), our paper focuses on the coal mining industry of Queensland (Qld) 
and New South Wales (NSW) as mining predominantly occurs in these two states. In NSW, coal mines constitute over $66 \%$ of all operating mines, with $60 \%$ in Qld (Geoscience Australia 2018).

In Queensland, there is approximately 220,000 ha of disturbed land, with an estimated rehabilitation cost of AUD 8.7 billion (Queensland Treasury Corporation 2017). Mining, by its nature, leaves land in a different state from when it started (Bowie \& Fulcher 2017) and can leave persistent non-natural landscape features (e.g. open pits, waste heaps, tailings storage facilities) (Doley \& Audet 2015). These land use areas, commonly referred to as domains (Department of Resources and Geoscience [DRG] 2013), present significant rehabilitation challenges. Different rehabilitation strategies are therefore needed to ensure chosen post-mine land uses can be achieved. This results in various post-mine land uses nominated for a site.

It is generally understood that mine rehabilitation is completed when the landform is demonstrated as being safe, stable, does not cause environmental harm, and is able to sustain the approved post-mining land use (Department of Premier and Cabinet [DPC] et al. 2017). The most common post-mining land uses achieved include agriculture (grazing and cropping), forestry, lakes (for multiple purposes), recreational areas, areas for nature and habitat conservation, sites for industrial or construction activities, and sites for backfilling other waste materials (Soltanmohammadi et al. 2010). It is general practice that mining companies will progressively rehabilitate mined land once it is no longer required for either extraction or operational purposes.

Public scrutiny of the performance of mining companies' rehabilitation efforts has never been greater. Recent changes in regulatory policy in both states (DPC et al. 2017; Department of Planning and Environment [DPE] 2017) aim to reduce state financial liability and a timely transition to post-mining land use. A focus of the reforms is for mining companies to explore land use options that could convert mining areas to beneficial economic uses post-mine closure. This may result in providing post-mining employment and economic opportunities for regional communities (DPC et al. 2017) and assist in limiting negative mine closure impacts on communities.

Selection of a post-mine land use is the single most important decision in mine closure planning, as all mine closure and rehabilitation activities should be defined based on the post-mining land use (Asia-Pacific Economic Cooperation 2018). Determination of an acceptable post-mine land use should ideally be identified through the consideration of community preferences, risk, internal business drivers, physical capabilities of the site, costs and benefits, planning schemes, location, and surrounding land uses. Additionally, regulatory policies and legislation influence the post-mine land use decision of a company (Maczkowiack et al. 2012). For example, in Qld the Rehabilitation Requirements for Mining Resources Activities ESR/2016/18 provides guidance for mining companies to define the post-mine land use with consideration of the rehabilitation hierarchy:

1. "Avoid disturbance that will require rehabilitation.

2. Reinstate a 'natural' ecosystem as similar as possible to the original ecosystem.

3. Develop an alternative outcome with a higher economic value than the previous land use.

4. Reinstate previous land use (e.g. grazing or cropping).

5. Develop lower value land use.

6. Leave the site in an unusable condition or with a potential to generate future pollution or adversely affect environmental values." Department of Environment and Science [DES] (2018a)

Commonly, rehabilitation might include restoring land to its pre-mining land use. In many instances, the pre-mining environment consists of native vegetation with varying levels of agricultural disturbance. Whilst Bastida (2002) identifies that lands should ideally be returned to its optimal economic use, in Australia current mine closure regulation, planning and implementation activities frequently focus only on environmental remediation (Harvey 2016). In more recent years, it is recognised that the aim to restore lands to previous ecosystem functions prior to disturbance is not necessarily optimal (Doley \& Audet 2013). 
This raises the question: 'If the rehabilitated land is not optimal to achieve the pre-mining land use, what are possible post-mine land use alternatives?'

Options for post-mining land use are many and varied. Some examples include aquaculture in the USA (Miller 2008); arable land use and the recently completed large-scale underground resort in China (Miao \& Marrs 2000; $A B C$ 2018); mining heritage, recreation, aesthetic values, regulating services, educational, cultural heritage and tourism in Spain (Perez-Alvares et al. 2016). Canada provides examples of wildlife habitats, forestry and pasture (Errington 2001), and Germany established recreation, tourism, and environmental conservation land uses through the rehabilitation of mine pit lakes (Ahlheim et al. 2004). The Eden Project in England is well recognised as an example of repurposing a disused mine where environmental education, recreation and scientific purposes are recognised as post-mining land uses (Pearman 2009).

It is important to note that the definition of mine rehabilitation is not interchangeable with post-mine land use. The Mining Act 1992 (NSW) (New South Wales Government 1992) defines rehabilitation as the "the treatment or management of disturbed land or water for the purpose of establishing a safe and stable environment". The NSW Mining Operations Plan Guidelines state that, at a minimum, "all rehabilitation should result in an agreed post-mining land use goal that is safe, stable, non-polluting and sustainable" (DRG 2013). A post-mining land use goal on the other hand is a statement describing the overall goal of the rehabilitation and mine closure process. Rehabilitation objectives and criteria should then be designed to support this goal. To achieve mine lease and rehabilitation bond relinquishment, a mine operation needs to demonstrate achievement of its post-mine land use goal.

When defining post-mine land use, it is crucial to define the utility value or function the land should provide after the cessation of mining (Kazmierczak et al. 2017). For example, simply stating that the site will be rehabilitated to a post-mining land use of 'agriculture' fails to descriptively identify the function of the area. A land use classification of 'agriculture' has a very broad interpretation. It could mean any type of livestock (intensive or not), cropping, or other agricultural products, that could utilise the area. These different land use functions, all require different levels of rehabilitation planning, rehabilitation methodology and techniques, landform design, execution, costs and time requirement for achievement. As such, it is imperative to consider the utility of the post-mine land use and describe it accordingly to ensure appropriate rehabilitation planning, execution and timely relinquishment.

The purpose of this paper is to provide information about pre- and post-mining land use trends in NSW and Qld coal mining sites. This information will be useful to identify future beneficial land uses as well as support decision- and policymaking at a landscape level. The paper first reflects on post-mine land use in the coal mining industry. Methods are presented in Section 2 and results in Section 3. Section 4 gives a discussion of the results and Section 5 concludes the research.

\section{$2 \quad$ Methods}

\subsection{The study area - New South Wales and Queensland}

Most of Australia's economic demonstrated resources (EDR) of black coal is located in Qld (61\%) and NSW (36\%) (Geoscience Australia 2017). The majority of coal mining in Qld occurs in the Bowen Basin. Significant black coal resources are also found in the Surat, Clarence-Moreton and Galilee basins in Qld; however, these are still relatively undeveloped. In NSW, the main EDR of black coal regions are Southern, Central, Sydney, Western, Newcastle and Gunnedah basins, with smaller mining basins at Oaklands and Gloucester. In this study, we assessed all known coal mines in these locations.

\subsection{Collection of data}

Datasets were created for each state and contain the mine name, location, operation type, operational status, pre- and post-mine land uses, and data sources. In some instances, multiple mines have been consolidated under one approval and are presented as a single record. Both open cut and underground 
coal mines, inclusive of those recognised as 'care and maintenance', are included in the analysis. Abandoned sites, historic sites or other commodities are not included, nor are projects or other related areas that hold separate environmental licences (e.g. coal handling preparation plants).

Terminology used by mine operators to describe their pre- and post-mine land uses and rehabilitation objectives (where no clear post-mine land use is explicitly stated) were recorded. For example, where a site has stated that rehabilitation aims to achieve 'the reinstatement of native vegetation', this has been recorded in the biodiversity category. Terminology was categorised into conservation, biodiversity, agriculture, residential, recreation, water management, industrial, infrastructure, forestry, mining or other (Table 1). The classification categories were based on broad land use considerations and terminology used by coal mining companies in both states. Frequency (count) data were recorded for each category, and sites can have multiple land uses. Where a site's defined pre- or post-mine land use (including consideration of rehabilitation objectives) was not identified, this has also been captured.

\section{Table $1 \quad$ Land use classification categories}

\begin{tabular}{ll}
\hline Category & Land use description \\
\hline Conservation & $\begin{array}{l}\text { Land used for conservation and heritage purposes. Includes state forests or } \\
\text { national parks. }\end{array}$ \\
Biodiversity & $\begin{array}{l}\text { Land used for revegetation (native or not), provision of habitat and corridors } \\
\text { for wildlife. Also includes where vegetation is identified but does not discuss } \\
\text { the specific use of these vegetation types. }\end{array}$ \\
Agriculture & $\begin{array}{l}\text { Land used for primary production. Includes cultivation of crops and animal } \\
\text { husbandry. }\end{array}$ \\
Residential & $\begin{array}{l}\text { Land used for residential dwellings for people to live in. Includes private } \\
\text { residential options (excludes industrial and commercial opportunities). }\end{array}$ \\
Recreation & $\begin{array}{l}\text { Land used by people for enjoyment. Can include both public and private } \\
\text { leisure activities. } \\
\text { Water management }\end{array}$ \\
Andustrial & $\begin{array}{l}\text { or artificial). } \\
\text { Land used for commercial enterprise options for industrial purposes (retail } \\
\text { goods and services, business and professional offices, manufacturing and } \\
\text { support services to business or industry). }\end{array}$ \\
Infrastructure & $\begin{array}{l}\text { Land used for physical and organisation structures and facilities (e.g. power } \\
\text { lines, rail lines, telephone lines and roads). } \\
\text { Land used for commercial enterprise options from managed plantations } \\
\text { (either native or introduced species). }\end{array}$ \\
Forestry & $\begin{array}{l}\text { Land used for mining and extractive industries. Can include mineral or gas } \\
\text { exploration. } \\
\text { Other land uses that cannot be categorised based on the descriptions above } \\
\text { (e.g. crown land, Department of Defence land). }\end{array}$ \\
\hline
\end{tabular}

In NSW, there is no publicly accessible register of mining operations. A database was created using information from the Australian Mines Atlas (Geoscience Australia 2018) and further populated using environmental protection licence searches in the public register under the Protection of the Environment Operations Act 1997 (Environmental Protection Agency 2018). Each mine operation's pre- and post-mine land use was sourced from the respective mine site's mining operations plan, development consent, assessment documents or other environmental management plans. This information is publicly available 
either on the mine operator's website or by reviewing the Department of Planning and Environment Major Project Assessment portal (DPE 2018).

In Qld there is also no publicly accessible register of mining operations. There is a public register of all environmental authorities issued under the Environmental Protection Act 1994 (DES 2018b). Appropriate mines were identified using this register and cross-referenced with the Qld coal mines and advanced projects publication (Department of Natural Resources and Mines 2017) to ensure all coal mines were captured. Where a mine's pre- or post-mine land use was not identified in the environmental authorities, searches were undertaken of operational mine company websites, government department environmental approval websites (Department of the Environment and Energy 2018; DES 2018c; State Development, Manufacturing, Infrastructure and Planning 2018) and the Department of Environment and Science \& Department of Natural Resources, Mines and Energy (2018) online libraries.

\section{Results}

We identified 61 coal mines in Qld and 65 in NSW, as of July 2018 (Table 2). Of these, not all pre- and postmine land uses could be identified. In Qld, there are nine mine sites where the pre-mine land use and two where the post-mine land use could not be determined. In NSW, five mine sites' pre-mine land use could not be identified, but all mine post-mine land uses were.

Table 2 Breakdown of mining operation sites and type in Qld and NSW (as of July 2018)

\begin{tabular}{lll}
\hline Operation type & Qld & NSW \\
\hline Open cut & 45 & 32 \\
Underground & 8 & 23 \\
Open cut/underground & 8 & 10 \\
Total & $\mathbf{6 1}$ & $\mathbf{6 5}$ \\
\hline
\end{tabular}

Results from our analysis identifying pre- and post-mine land uses for mines in NSW and Qld are shown in Figures 1 and 2. The pre-mining land use is dominated by agriculture, with $82 \%$ (50 sites) in Qld and 71\% (46 sites) in NSW identifying this land use.

The most frequently nominated post-mine land uses are biodiversity (with 48 (79\%) sites in Qld and 63 (97\%) in NSW) and agriculture (with 74\% of sites in Qld and 60\% in NSW). All sites in NSW and $98 \%$ in Qld have chosen biodiversity and/or agriculture as a post-mine land use. In Qld, one site nominated an industrial post-mine land use.

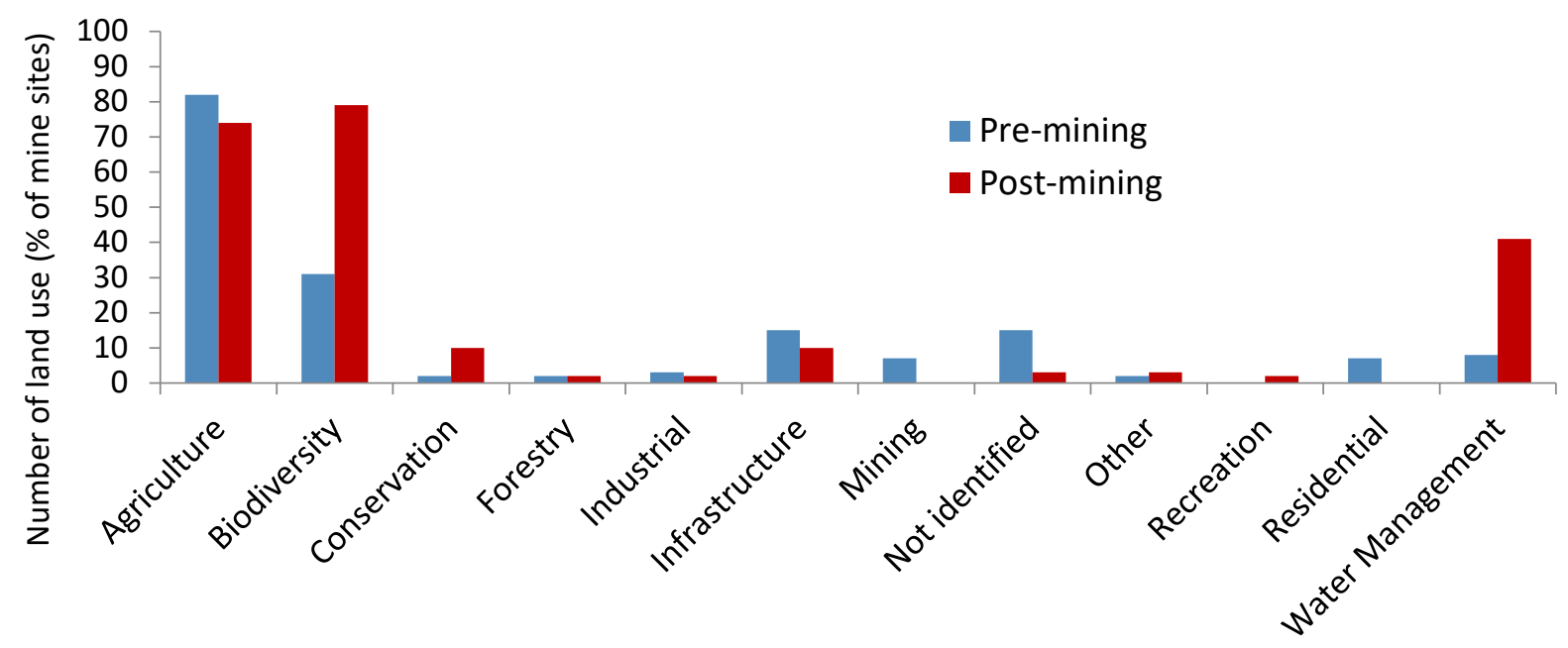

Land use types

Figure 1 Qld identified pre-mining and post-mining land uses (\% of sites), $n=61$ 


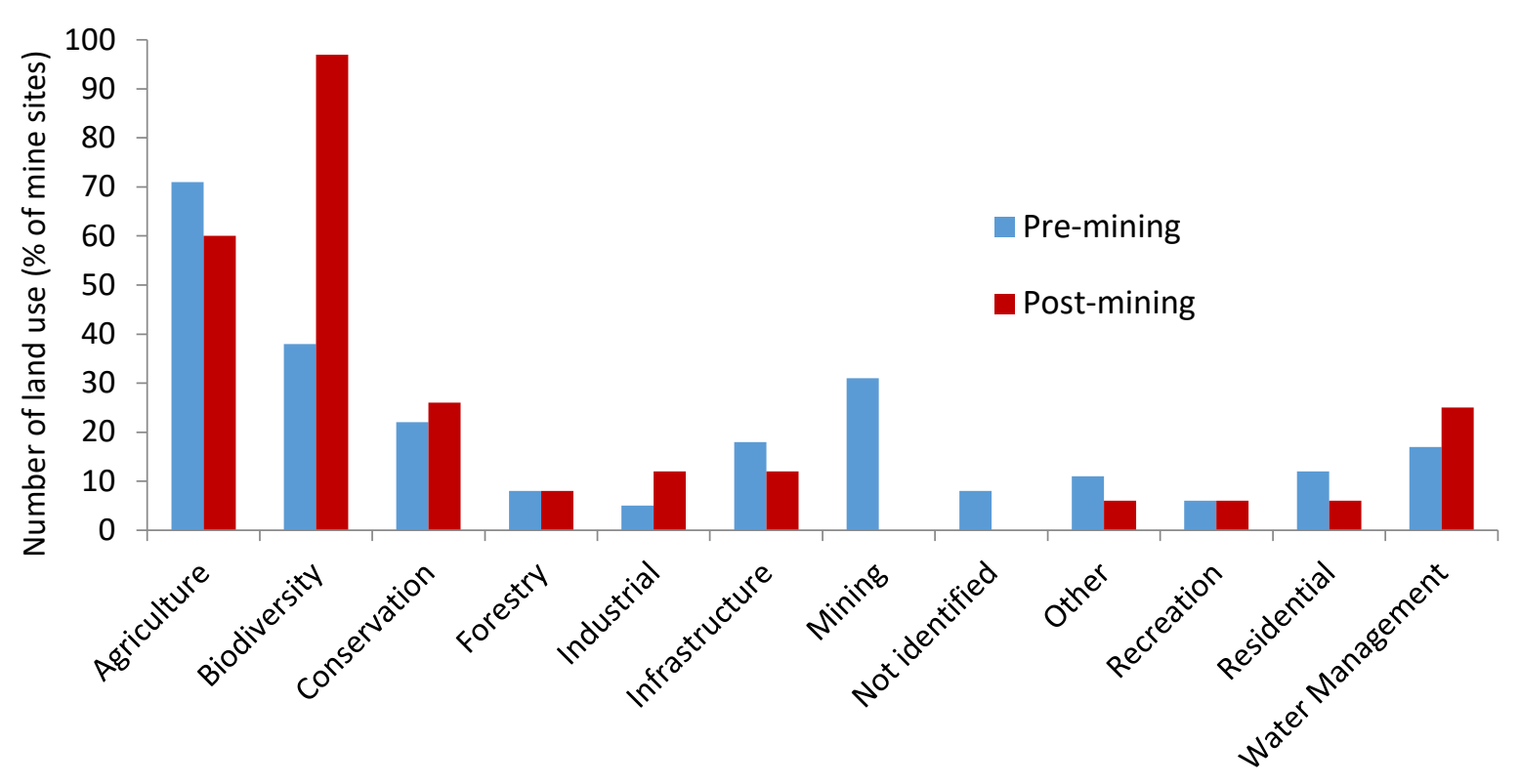

Land use types

Figure 2 NSW identified pre-mining and post-mining land uses (\% of sites), $n=65$

Each individual mining site's pre- and post-mining land uses were compared to understand how many sites were reinstating their pre-mining land uses (Table 3). Sites that do not identify any pre- or post-mine land use and sites that identified mining as the pre-mine land use were excluded from these calculations as mining does not occur post closure (40 sites). In Qld, 11 sites (24\%) and five sites in NSW (13\%) intend to reinstate the same pre-mine land use at closure. Other sites may reinstate the original land use, with the addition of other land uses. Results show that 24 sites (52\%) in Qld and 18 (45\%) sites in NSW nominated a combination of post-mine land uses that included at least the pre-mining land use.

Table 3 Comparison of pre-mining land use to post-mining land use, $n=126$

\begin{tabular}{|c|c|c|}
\hline Scenario & Qld & NSW \\
\hline Site reinstating the same pre-mining land use (like for like) & 11 & 5 \\
\hline $\begin{array}{l}\text { Site reinstating the same pre-mining land use with additional land } \\
\text { uses (original + additional) }\end{array}$ & 24 & 18 \\
\hline Site reinstating new land use (not the observed pre-mining land use) & 11 & 17 \\
\hline Number of excluded sites (pre- or post-mining land use not identified) & 11 & 5 \\
\hline Number of excluded sites (mining identified as pre-mining land use) & 4 & 20 \\
\hline Total & 61 & 65 \\
\hline
\end{tabular}

The number of pre- and post-mining land use was recorded. In Qld, most sites identified one pre-mining land use (26 sites (43\%)), whereas in NSW two pre-mine land uses were commonly identified (at 21 (32\%) of sites). It was relatively common to nominate two or three post-mine land uses (Figure 3). About $15 \%$ of all sites identified four or more post-mine land uses. 


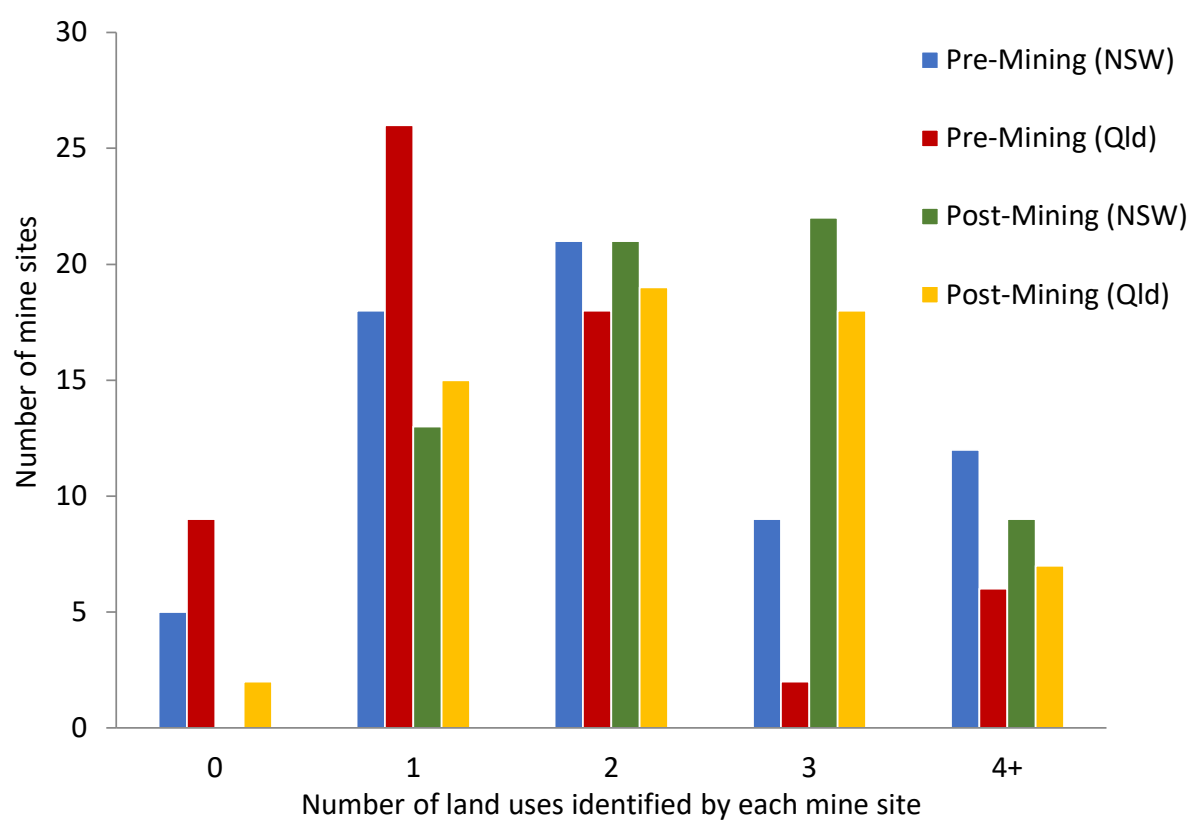

Figure 3 Number of pre- and post-mining land uses identified by each mine site

Details were also recorded to identify changes between the number of identified pre- and post-mine land uses (Table 4). In both states, sites tend to increase the number of land uses types post-mining compared to the number of identified land uses during pre-mining stages.

Table 4 Change in sites' land use types in each state $(n=61$ Qld, $n=65$ NSW)

\begin{tabular}{lll}
\hline Scenario & Qld & NSW \\
\hline Same number of pre-mine land uses compared to post-mine land uses & $13(21 \%)$ & $15(23 \%)$ \\
Number of post-mine land uses increased from pre-mining land use & $38(62 \%)$ & $30(46 \%)$ \\
Number of post-mine land uses decreased from pre-mining land use & $10(16 \%)$ & $20(30 \%)$ \\
\hline
\end{tabular}

Terminology used by mine operators to describe their pre- and post-mine land uses and rehabilitation objectives (where no clear post-mine land use is explicitly stated) were recorded. The data are presented for pre-mining land use in Appendix 1 and post-mining land use in Appendix 2. On multiple occasions, sites' rehabilitation objectives were used to infer the post-mine land use (as it was not explicitly stated). It was also common for sites to use non-descriptive terminology when detailing post-mine land uses. For example, a site may just state 'agriculture' when describing the post-mine use.

\section{Discussion}

The most frequently nominated post-mine land uses in both states are biodiversity and agriculture, with over $98 \%$ of sites in Qld and $100 \%$ in NSW choosing one (or both) of these land uses. In Qld, the influence of policy may provide some insight for this land use dominance. As outlined within the rehabilitation hierarchy contained within the DES (2018a), there is a preference for post-mining land use to be a 'natural' ecosystem, similar to the original ecosystem. However, such hierarchy does not necessarily allow the development of an alternative outcome with a higher economic value than the previous land use (Doley et al. 2012). The requirement for mining companies to investigate beneficial land uses for post-mining land is a consideration of the regulatory reform in both states. As such, we may see changes to the dominance of the current post-mine land uses in the future.

In both states, agriculture is the most common pre-mining land use. There is limited evidence that mine operators are likely to remain consistent with the pre-mining land use, with about half of the sites in each 
state reinstating their original land uses (even with additional uses). Some sites have steered away altogether from re-establishing a land use that was present before mining and have instead opted to introduce new land uses. In NSW, $26 \%$ of sites and $18 \%$ in Qld have chosen not to reinstate a pre-mining land use. It is not uncommon for community members to expect that a mining company will simply put the mine area back to what was once there. It is suggested that if the pre-mining land use was grazing, and the neighbourhood land use is still dominantly grazing, local community expectation is that the post-mining land use should be grazing (Bowie \& Fulcher 2017).

Sites tend to increase the number of land uses identified when nominating their post-mine land use compared to the number identified during pre-mining. Sites are made up of land disturbance domains that contain different landscape features. These domains require different rehabilitation strategies and will result in various land uses for each site. At the very least, most sites will maintain at closure a final void, rehabilitated spoil heaps and mineral waste facility (e.g. tailings dam). As such, it is not surprising to see sites commonly choosing two or more post-mine land uses.

We encountered difficulties in finding information about the number of mine operations and the identification of pre- and post-mine land uses, as there is no public register of mine operations in either state. In Qld, the task was made more difficult because most mining companies provide very limited public information on environmental management, as there is no legislative requirement to do so (as there is in NSW). In both states, approval documents do not always identify the sites' post-mine land use, which required the information to be sourced from other documents (Section 2.2). Consultation and building trust between mining companies and community may be made harder without access to such information. Public information on proposed post-mine land uses can assist in the identification of future alternative land uses as well as support decision-making and policymaking.

In some in instances, sites' rehabilitation objectives were used to infer post-mine land uses. Without a defined post-mine land use, this can lead to unsuitable development of rehabilitation criteria, ineffective decision-making, negative financial implications, risks and delays to mine closure, as well as potential liabilities to the public. The description of the post-mine land use should be an explicit statement and be aligned with the utility value of the rehabilitation. In describing a post-mine land use (Appendix 2), mining companies, in many instances, used non-descriptive language that failed to account for the potential use of the rehabilitation or mine site as a whole. For example, having a post-mine land use of 'bushland' fails to identify a potential use. Potential uses may include ecosystem services, aesthetics, biodiversity values, cattle grazing, forestry, recreation, carbon sequestration or scientific values, for example.

\section{Conclusion}

In conclusion, the most common post-mine land uses in the coal mining industry of NSW and Qld are agriculture and biodiversity compared to agriculture being the dominant pre-mining land use. Sites also commonly nominated a combination of post-mine land uses, with over $85 \%$ of all sites nominating between one to three post-mine land uses. Results found limited evidence to show that operations are more likely to remain consistent with the land use present at pre-disturbance, with only about half of all sites reinstating pre-mining land use(s), even with the addition of others. Several sites are proposing new land use(s) to those observed pre-mining land use. Furthermore, it was observed that mine sites tend to use nondescriptive language and may not consider the utility value of the rehabilitation when detailing the postmine land use(s).

\section{Acknowledgement}

Karin Fogarty is a recipient of the AusIMM EEF PhD scholarship award. Marit Kragt is funded by the Australian Government as an Australian Research Council Discovery Early Career Researcher Award (DE160101306) and received UWA Fellowship support. The authors thank the reviewers for feedback and comments received. 


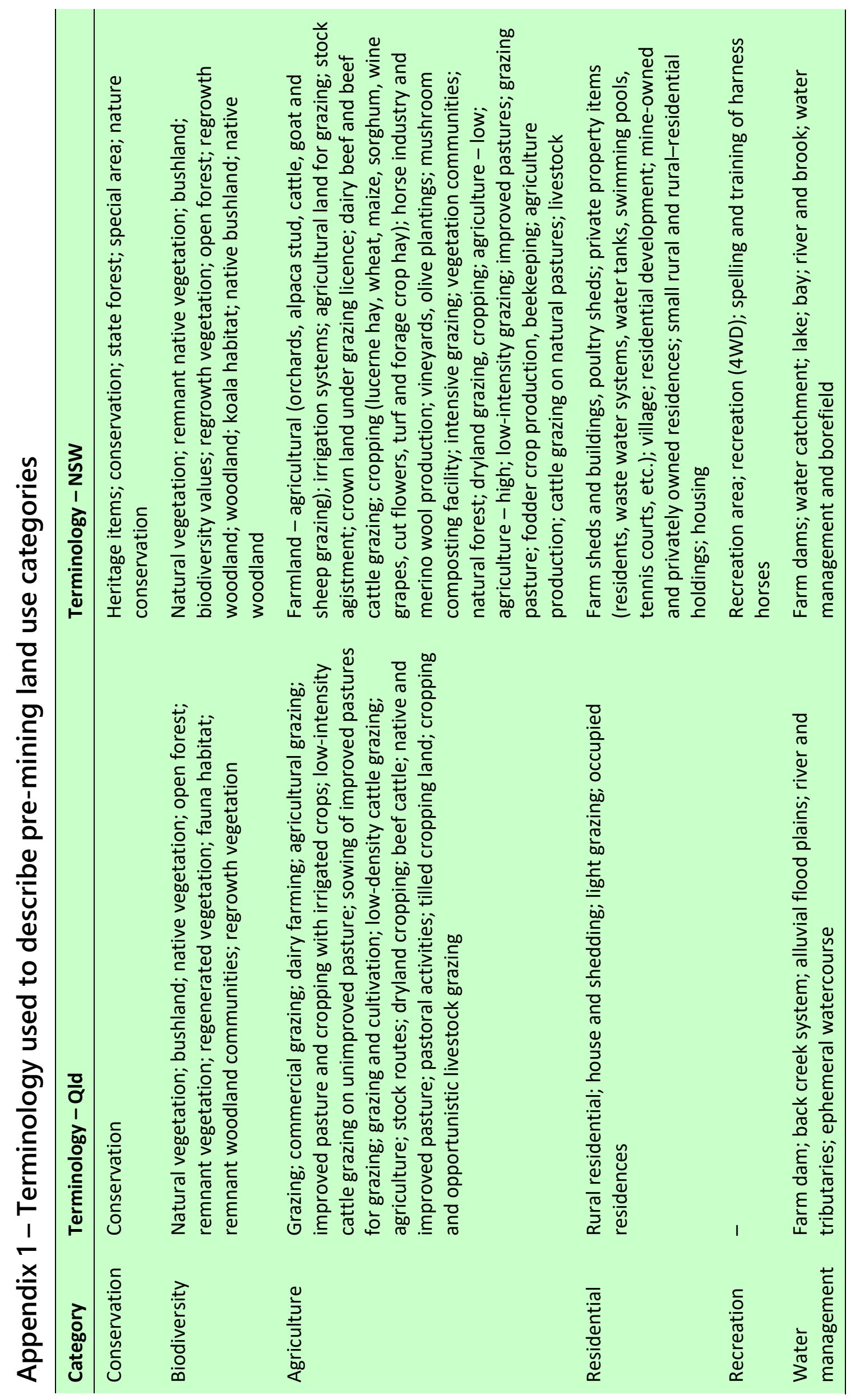




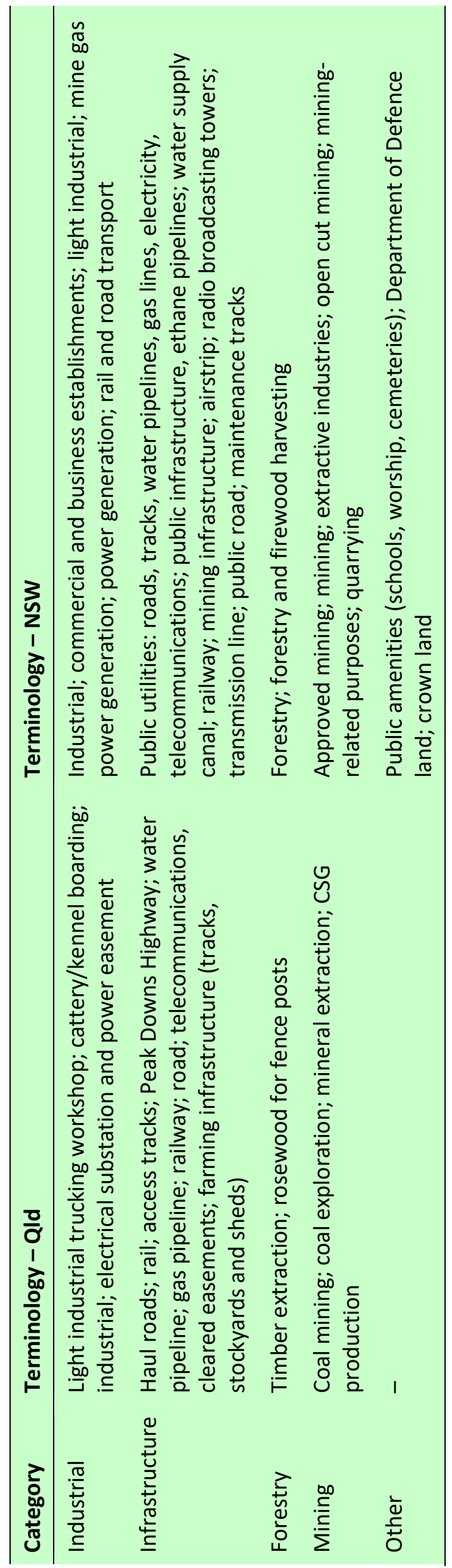




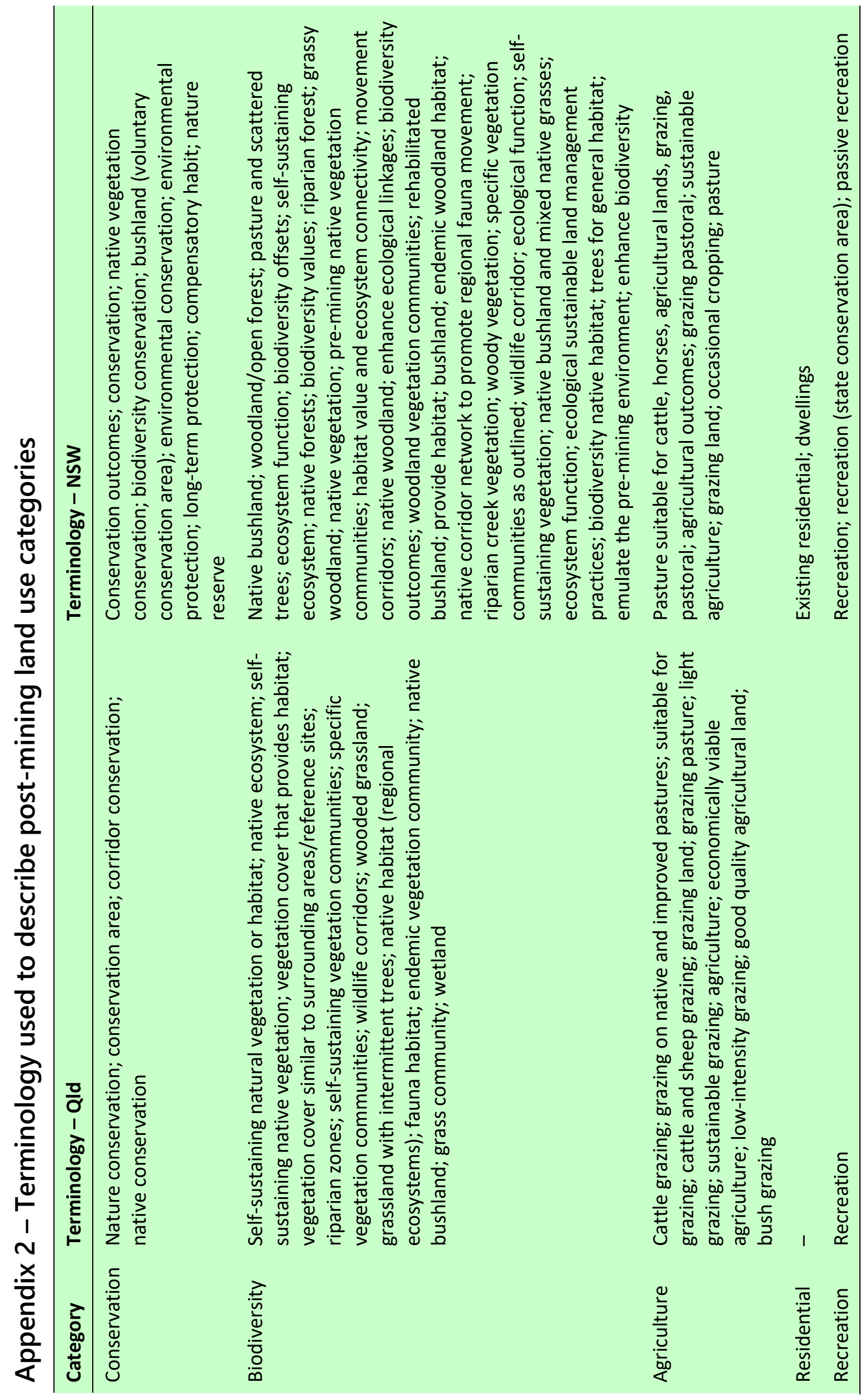




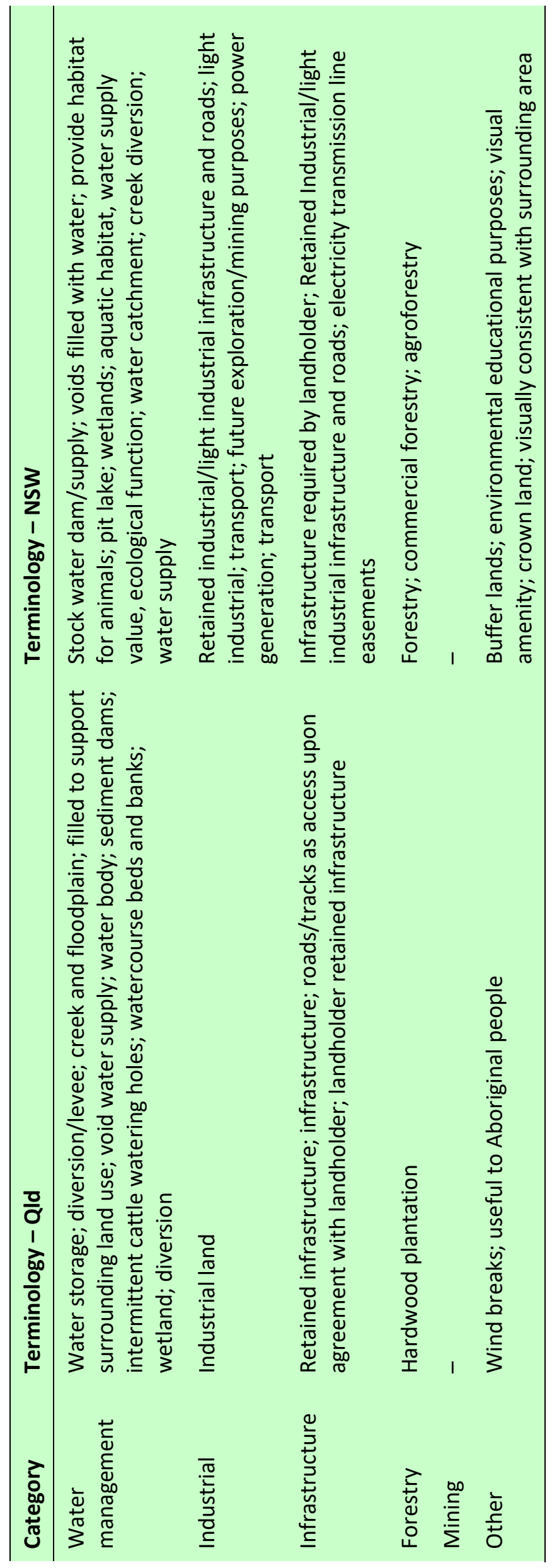




\section{References}

ABC 2018, 'World's first "ground-scraper" hotel built in former quarry opens its doors to the public in China', $A B C$ News, viewed 22 November 2018, https://www.abc.net.au/news/2018-11-20/worlds-first-groundscraper-opens-in-shanghai/10510522

Ahlheim, M, Fror, O, Lehr, U, Wagenhal, G \& Wolf, U 2004, Contingent Valuation of Mining Land Reclamation in East Germany Discussion Paper, University of Hohenheim, Stuttgart.

Asia-Pacific Economic Cooperation 2018, Mine Closure Checklist for Governments, Singapore.

Bastida, E 2002, 'Integrating sustainability into legal frameworks for mining in some selected Latin American countries', Mining, Minerals and Sustainable Development, vol. 120, pp. 1-33.

Bowie, L \& Fulcher, J 2017, 'Planning for post-mining land uses', paper presented at the Planning Institute of Australia (Qld) Annual Conference, Bundaberg, 14 September.

Department of Environment and Science 2018a, Rehabilitation Requirements for Mining Resource Activities, ESR/2016/1875, Version 2.01, Brisbane.

Department of Environment and Science 2018b, Environmental Authorities Register, Brisbane, viewed 30 May 2018, https://apps.des.qld.gov.au/env-authorities/

Department of Environment and Science 2018c, Current and Concluded EIS Process Projects, Brisbane, viewed June-August 2018, https://environment.des.qld.gov.au/management/impact-assessment/eis-processes/current.html

Department of Environment and Science \& Department of Natural Resources, Mines and Energy 2018, Library Services, Brisbane, viewed June-August 2018, https://qldgov.softlinkhosting.com.au/liberty/libraryHome.do

Department of the Environment and Energy 2018, EPBC Notices Referral Lists, Canberra, viewed June-August 2018, http://epbcnotices.environment.gov.au/referralslist/

Department of Industry 2016, Mine Closure Leading Practice Sustainable Development for the Mining Industry, Australian Government, Canberra.

Department of Industry, Innovation and Science 2019, Resources and Energy Quarterly - March 2019, viewed 2 June 2019, https://publications.industry.gov.au/publications/resourcesandenergyquarterlymarch2019/documents/Resources-and-EnergyQuarterly-March-2019.pdf

Department of Natural Resources and Mines 2017, Queensland Coal - Mines and Advanced Projects, Brisbane, viewed June 2018, https://www.dnrm.qld.gov.au/_data/assets/pdf_file/0011/238079/coal-mines-advanced-projects.pdf

Department of Planning and Environment 2017, Improving Mine Rehabilitation in NSW Discussion Paper, Sydney, viewed November 2017, https://www.planning.nsw.gov.au/-/media/Files/DPE/Discussion-papers/Improving-mine-rehabilitationin-NSW-Discussion-paper-November-2017.pdf

Department of Planning and Environment 2018, Major Project Assessment Portal, Sydney, viewed June-August 2018, http://www.majorprojects.planning.NSW.gov.au/index.pl?action=search\&status_id=6\&status_id=117\&status_id=116\&stat us_id $=114$

Department of Premier and Cabinet, Department of Natural Resources and Mines, Queensland Treasury \& Department of Environment and Heritage Protection 2017, Better Mine Rehabilitation for Queensland Discussion Paper (\#31261), Brisbane, viewed April 2017, https://s3.treasury.qld.gov.au/files/better-mine-rehabilitation-in-qld-discussion-paper.pdf

Department of Resources and Geoscience 2013, ESG3 Mining Operations Plan MOP Guidelines, Sydney.

Doley, D \& Audet, P 2013, 'Adopting novel ecosystems as suitable rehabilitation alternatives for former mine sites', Ecological Processes, vol. 2, pp. 1-11.

Doley, D \& Audet, P 2015, 'Identifying natural and novel ecosystem goals for rehabilitation of postmining landscapes', in ME Jarvie-Eggart (ed.), Responsible Mining: Case Studies in Managing Social and Environmental Risks in the Developed World, Society for Mining, Metallurgy and Exploration, Englewood, pp. 609-638.

Doley, D, Audet, P \& Mulligan, D 2012, 'Examining the Australian context for post-mined land rehabilitation: Reconciling a paradigm for the development of natural and novel ecosystems among post-disturbance landscapes', Agriculture Ecosystems and Environment, vol. 163, pp. 85-93.

Environmental Protection Agency 2018, Protection of the Environment Operations, POEP Public Register, Sydney, viewed 28 May 2018, http://app.epa.nsw.gov.au/prpoeoapp/

Errington, J 2001, 'Mine reclamation in British Columbia - twenty-five years of progress', Proceedings of the 25th Annual British Columbia Mine Reclamation Symposium, https://dx.doi.org/10.14288/1.0042385

Geoscience Australia 2017, Australia's Identified Mineral Resources 2017, Symonston, viewed June 2018, http://www.ga.gov.au/_data/assets/pdf_file/0005/58874/Australias-Identified-Mineral-Resources-2017.pdf

Geoscience Australia 2018, Australian Mines Atlas, Symonston, viewed 28 May 2018, http://www.australianminesatlas.gov.au/mapping/files/operating_mines.xls

Harvey, B 2016, 'The eye of the beholder - utility and beauty in mine closure', in AB Fourie \& M Tibbett (eds), Proceedings of the Eleventh International Conference on Mine Closure, Australian Centre for Geomechanics, Perth, pp. 17-24.

Kazmierczak, U, Lorenc, M \& Strzalkowski, P 2017, 'The analysis of the existing terminology related to a post-mining land use: a proposal for new classification', Environmental Earth Science, vol. 76, pp. 693.

Lechner, A, Kassulke, O \& Unger, C 2016, 'Spatial assessment of open cut coal mining progressive rehabilitation to support the monitoring of rehabilitation liabilities', Resources Policy, vol. 50, pp. 234-243.

Maczkowiack, R, Smith, C, Slaughter G, Mulligan D \& Cameron D 2012, 'Grazing as a post-mining land use: A conceptual model of the risk factors', Agricultural Systems, vol. 109, pp. 76-89. 
Miao, Z \& Marrs, R 2000, 'Ecological restoration and land reclamation in open-cast mines in Shanxi Province, China', Journal of Environmental Management, vol. 59, pp. 205-215.

Miller, D 2008, 'Using aquaculture as a post-mining land use in West Virginia', Mine Water Environment, vol. 27, pp. $122-126$.

Minerals Council of Australia 2017, Submission to Senate Environment and Communications Reference Committee Inquiry into the Rehabilitation of Mining and Resources Projects as it Relates to Commonwealth Responsibilities, viewed August 2018, https://minerals.org.au/news/mca_submission_to_the_senate_inquiry_into_mine_rehabilitation

New South Wales Government 1992, Mining Act 1992 (NSW)

Pearman, G 2009, 101 Things to Do With a Hole in the Ground, Post Mining Alliance, Bodelva, UK.

Perez-Alvares, R, Torrest-Ortega, S, Diaz-Simal, P, Husillos-Rodriguez, R \& De Luis-Ruiz, J 2016, 'Economic valuation of mining heritage from a recreational approach: application to the case of El Soplao Cave in Spain (Geosite UR004)', Sustainability, vol. 8, pp. 185

Queensland Treasury Corporation 2017, Review of Queensland's Financial Assurance Framework. Final Report: Version for Public Consultation, Brisbane, viewed June 2018, https://s3.treasury.qld.gov.au/files/review-of-queenslands-financial-assuranceframework.pdf

Soltanmohammadi, H, Osanloo, M \& Aghajani Bazzazi, B 2010, 'An analytical approach with a reliable logic and a ranking policy for post-mining land-use determination', Land Use Policy, vol. 27, pp. 364-372.

State Development, Manufacturing, Infrastructure and Planning 2018, Coordinated Projects Portal, Brisbane, viewed June-August 2018, http://statedevelopment.qld.gov.au/assessments-and-approvals/coordinated-projects.html

World Energy Council 2015, Energy Resources: Coal, London, viewed August 2018, https://www.worldenergy.org/data/resources/ resource/coal/ 